\title{
Risk Analysis in a Manufacturing Company's Inventory Cycle
}

\author{
Hana Nurila Alfatin \\ Department of Accounting \\ Faculty of Economics and Business, Universitas Indonesia \\ Jakarta, Indonesia \\ hananurila@gmail.com
}

\author{
Lianny Leo \\ Department of Accounting \\ Faculty of Economics and Business, Universitas Indonesia \\ Jakarta, Indonesia \\ 1lianny11@gmail.com
}

\begin{abstract}
This study aims to analyze risk management in the inventory cycle of manufacturing companies and aims to provide recommendations to reduce identified risks. This study uses small and medium enterprises as a case study because it has limited resources to respond to potential risks that threaten business continuity. The method used is qualitative descriptive method with case study approach. Data obtained through document analysis, observation, and in-depth interview. The results show that there are risks identified in the inventory cycle that have not been mitigated by the company's internal controls. Risk maturity assessment conducted before the study showed that the company was at the risk level of naïve and increased to risk defined after the research.
\end{abstract}

Keywords—Risk analysis, Inventory cycle, Manufacturing, Small medium enterprise

\section{INTRODUCTION}

\section{A. Research Problem}

According to the United Nations Industrial Development Organization Report, Indonesia's manufacturing industry is currently among the top 10 in global manufacturing [1]. In manufacturing companies, activities in the inventory cycle include purchasing and receiving raw materials, storage of raw materials, goods processing, storage of finished goods, and delivery of finished goods [2]. Inventories in the manufacturing industry are often the most dominant accounts in a company's balance sheet, and they cannot be separated from operational activities that could significantly affect the company's ability to meet customer needs [3].

PT HS is a producer of Educational Game Equipment, with its main target consumers are preschool and kindergarten children. The company does mid-scale manufacturing, producing various types of children's educational games. Based on initial interviews with the general manager, PT HS has experienced several obstacles in its operations, especially in the inventory cycle. Events with negative impact constitute risks that can inhibit value creation or reduce existing value [4], but the company has not yet taken a risk management approach despite intending to do so to improve its overall management. As a manufacturing company, surely the inventory cycle is the main focus. A company may decide to insure risks directly for risk protection, while some choose to use risk management as a tool to understand and evaluate risk as an option other than insuring it [5]. Risk management can be a cost-effective alternative to insuring risks.

Small and medium enterprises (SMEs) require adoption of risk management strategies and methodologies, because they usually have limited resources to respond to internal and external threats that can potentially harm the company's viability [6]. In fact, risk management in SMEs differs from that in large-scale enterprises because large-scale companies tend to manage risks collectively, while in SMEs, risk management is often performed by company owners who may be supported by small management teams [7]. Implementation of risk management can help SMEs adjust to a dynamic environment to gain strategic advantage and to enhance competitiveness and business success [8].

Risk management can be arranged using the International Standardization Organization (ISO) 31000: 2009 approach, an international risk management standard applicable to a wide range of organizations in any country, for any type of operation, regardless of complexity, size, or type [9]. Risk management is a complementary part of internal control that can be different depending on each company's specific needs [10]. Based on this background, research discusses appropriate risk management design for a company, including identifying significant risks and their impacts related to the inventory cycle, performing risk assessment and risk management, and providing risk mitigation recommendations. This study's purpose is to describe risk management design of a manufacturing company's inventory cycle. Mitigation considers the efficiency of the company's concern on a SME scale.

\section{B. Research Questions}

1. What risk management design is appropriate to mitigate negative impacts of risks identified in the inventory cycle?

2. What efforts can the company take to optimize the risk management design?

\section{Research Objective}

1. Analyze a risk management design to help the company mitigate the negative impact of risks identified in the inventory cycle.

2. Analyze activities the company could do to optimize the risk management design.

\section{Research Benefits}

This research is expected to provide contributions for some parties as follow:

1. For students, this study can increase insight into risk management of a manufacturing industry's inventory cycle.

2. For academics, the study can be used as a reference for further research on development of risk management in manufacturing industries. 
3. For the company, this study can help to improve understanding of risk management, especially of the inventory cycle, and thus increase productivity according to company strategy.

\section{F. Section Outline}

This research consists of five sections, including: introduction, theoretical review, research methodology, discussion, conclusion, and suggestions.

\section{THEORETICAL REVIEW}

\section{A. Agency Theory}

Agency theory describes a relationship between one or more parties who act as principal involving other parties who act as agent to perform an action or activity on behalf of the principal that involves delegation of decisionmaking to the agent [11]. This theory emerged because of agency problems not only between company principals with the management as agent, but also between majority and minority shareholders [12]. The cooperative relationship between a company owner and management is represented by a contract of cooperation, so agency theory focuses on determining the efficiency of the contract that links the owner's interests to that of management [11]. Scott [13] posits two types of asymmetric informationadverse selection and moral hazard. Linking agency theory to small and medium-sized businesses, Ang [14] explains several agency problems, for example, owners who also serve as night operators and lenders, issues with unions and with suppliers who exercise monopoly over small businesses.

\section{B. Risk}

\section{Definition}

The ISO [15] defines risk as the impact of a goal's uncertainty. Risk, according to Kasidi [16], is the possibility of deviation from hope that cause losses, while Hanafi [17] defines risk as an adverse event. Darmarwi [18] explains the concept of risk as the probability of an outcome different from that expected. These definitions conceptualize risk as the possibility of an event producing results not in accordance with expected results and causing harm to an entity.

D. Types of Risk

Moeller [5] classifies companies' risks into several types:

1. Strategic risk includes external risks influenced by factors outside the company and internal risks influenced by factors within the company.

2. Operational risk includes operational, compliance, and people risks.

3. Financial risk is affected by treasury, credit, and trading risks.

4. Information risk is divided into financial, operational, and technology risks.

\section{E. Risk Management}

\section{F. Definition}

According to the ISO [15], risk management is a coordinated activity to direct and control organizations' uncertainty and insecurity. Pickett [19] defines risk management as a dynamic process for taking reasonable steps to recognize and deal with uncertainties that impact corporate goals. Kaskidi [16] explains that risk management is the design and implementation of procedures for managing business unpredictability and instability. From these definitions, we conclude that risk management is a systematic effort to formulate appropriate measures to address risk and minimize its impact.

\section{G. Relationship between Risk Management and Internal Control}

Risk management supports internal control to achieve corporate goals. Corporate governance is the company's overall concept, which is heavily influenced by risk management and an efficient internal control system. The company's three major sections (governance, risk management, and internal control) form an entire system that delivers effective performance and stakeholder accountability [19].

\section{H. Risk Management Process}

Pickett [19] and Moeller [5] divide risk management into four stages:

1. Identification: Drennan [20] outlines some identification strategies, including training, questionnaires and surveys, analysis of historical data, physical examination, flowcharts, and risk registers.

2. Assessment considers risk likelihood and potential impact.

3. Management includes developing strategies for overseeing risks with high likelihood and impact.

4. Review includes updating identification, assessment, and risk management strategies and reviewing the validity of processes implemented throughout the organization.

\section{Risk Management based on COSO Enterprise Risk Management (COSO ERM)}

Moeller [5] defines Enterprise Risk Management as a process undertaken by the board of directors, management, and other company departments. It is applied in overall corporate strategy and designed to identify potential events that might affect the company's condition, to manage risk according to the company's needs, and to provide reasonable assurance regarding achievement of corporate objectives. Moeller [5] outlines eight key elements of the Committee of Sponsoring Organizations Enterprise Risk Management (COSO ERM) framework including Internal Environment, Objective Setting, Event Identification, Risk Assessment, Risk Response, Control Activities, Information and Communication, and Monitoring.

\section{J. Risk Management Process based on ISO 31000:2009}

ISO 31000: 2009 is an international standard on risk management practices published in November 2009. A group of technical advisors from 18 countries developed this standard during six meetings over several years, by updating AS / NZS 4360: 2004, which is the prevailing risk management standard in Australia and New Zealand. This standard was created for all types of organizational operations, regardless of complexity, size, and type. 
Gjerdrum and Peter [9] describe some of the differences between ISO 31000: 2009 and the COSO ERM framework. First, COSO ERM is complex and difficult to implement, while ISO provides a more understandable approach. Second, ISO is based on management process and adapts the process to each organization, integrating it into existing strategic management and initiatives. Conversely, COSO is based on controls and compliance difficult for traditional risk managers to accept. Third, if COSO is implemented by an organization's internal audit team, it creates a constraint if the implementing party conducts the audit process, while ISO allows the audit function to play a role in the monitoring and review phase. Last, COSO is composed of auditors, accountants, and financial experts, while ISO is composed of risk management practitioners and international standard experts.

The risk management process in ISO 31000: 2009 consists of five stages:

1. Communication and Consultation

2. Establishing the Context

3. Risk Assessment (including risk identification, analysis, and evaluation)

4. Risk Treatment

5. Monitoring and Review

\section{K. Risk Maturity}

Madendre defines risk maturity as the ability and level of adaptation and implementation of robust risk management at every business level for determination, identification, and reporting of attitudes toward opportunities and threats that affect entity goals [21]. The Institute of Chartered Accountants of India [22] classified risk maturity into five categories: risk naïve, risk aware, risk defined, risk managed, and risk enabled.

\section{Inventory Cycle}

Inventory is the most active aspect in the company's operational activity-continuously obtained and transformed through a process to be resold [23].

\section{RESEARCH METHODOLOGY}

\section{A. Research Approach}

This research uses a single case study approach, with analysis of a single unit, because case studies allow researchers to obtain in-depth data [24].

\section{B. Scope of Research Analysis}

This study's scope focuses on the risk of inventory cycles associated with the research object, i.e., PT HS, whose head office is in East Jakarta, with warehouses and factories in Depok and Bogor, West Java, because researchers have found various problems in the company, like those described in the background. The study's research framework is ISO 31000: 2009.

\section{Research Design}

This research uses a single case study approach with the qualitative exploratory method and single unit analysis. Qualitative methods are developed in various social sciences to enable researchers to study cultural phenomena that require numerical data [25]. Qualitative research [25] focuses on development of theory, considers real practice, has a non-numerical value, and is inductive when a hypothesis is not required to begin the study. Exploratory research aims to improve understanding of a problem [26] and can also be used in social sciences by conducting transparent, honest, and reflexive research, and following guidelines to ensure research reliability [27]. Wahyuni [26] explains several main ways of conducting exploratory research, including literature searches and interviews. Here, we used the case study approach because case studies allow researchers to obtain in-depth data [24]. The case study method has been widely used as a research tool, and its purpose is to obtain information from the actual situation [28].

\section{Unit of Analysis}

Here, the unit of analysis is PT HS. The company has not yet arranged a risk management approach despite intending to do so to improve company management.

\section{E. Data Collection Procedures}

The study was conducted in several stages, as follows:

1. Collect primary data from interviews and secondary data from company documents; conduct a literature review related to risk management.

2. Conduct interviews and observations for risk management design as follows:

a. Communication and consultation: Review the company's data and perform risk maturity assessment to determine the level of corporate risk maturity before designing risk management.

b. Setting the context: The researcher consults with related parties to determine objectives, scope, external and internal factors, and the classification and criteria of each risk.

c. Risk identification: Interviewing and observing with those who have expertise related to the inventory cycle to identify its risks.

d. Risk analysis: Identified risks are considered on the bases of their likelihood and impact. Risk is then classified in the FGD process so that those with special expertise are also involved in determining risk classification.

e. Risk evaluation. Risks have been classified as to likelihood and impact. Then they are evaluated and the risks are mapped to determine appropriate mitigation preferences.

f. Risk treatment. From mapped risks are designed mitigation proposals to reduce the likelihood and/or impact of each risk.

g. Monitoring and review. The researcher reviews the extent to which the risk management design can play a role for the company by conducting risk maturity assessment. 


\section{DISCUSSION}

\section{A. Risk Management Design for Inventory Cycle}

B. Risk Identification and Risk Impact on Inventory Cycle

a) Risk of Purchasing Raw Materials

1. Buying low quality raw materials due to dependence on a single supplier; the company has no written procedure on supplier control.

2. Purchasing unnecessary raw materials due to distance between supplier location and production unit, but not yet applying a perpetual record system or inventory management of raw material.

3. Inaccurate raw materials recording because the company has not implemented a system of inventory recording.

4. Unreliable supplier because the company relies on only one supplier.

5. Receiving raw materials unfit for orders, caused by lack of a special thickness gauge; no written procedure for inspection of goods received; limitations of document access between units.

\section{b) Risk of Raw Material Storage}

6. Decreasing quality of raw materials because they are moldy and fragile; raw materials have not been organized neatly; no room has been specially allocated as a raw material storage warehouse.

7. Loss of raw materials due to lack of neat organization; lack of raw material management procedures; inadequate inventory documentation support; no restriction on accessing raw materials.

8. Loss of raw materials due to flammability and fire; placing raw materials in locations with high electricity use, lack of fire protection system; no room allocated as a raw material storage warehouse.

9. Late purchases of raw materials due to lack of implemented raw material inventory management.

c) Risk in Production Process

10. Accidents by production operators, caused by many machines needing manual operation; inconsistently applied safety standards; production operators' low awareness of accident risk.

11. Production operators' health problems due to low awareness of health risk.

12. The wood is moldy because of the production unit's indoor humidity; weather conditions affecting humidity; received raw materials contain mushroom seeds due to moisture.

13. Manually operated timber cutting does not meet specifications; decreased operator concentration in wood cutting; resulting errors in wood planks.

14. Power outage due to PLN's rotating power cuts and electricity repairs.

15. Production machinery's decreased performance due to decline in economic life; machinery use exceeds its capacity; lack of routine maintenance procedures.

d) Risk in Finished Goods Storage

16. Loss of finished goods inventory caused by several factors: lack of separate warehouses at some points; lack of inventory organization; lack of procedures for managing finished goods inventory; lack of documentation for finished goods inventory; no restriction on access to finished goods inventory.

17. Obsolescence of finished goods inventory due to its slow turnover; management of finished goods inventory not applied; lack of systematic inventory recording; inventories not neatly organized; no established method of calculating inventory or use of "first-in-first-out" (FIFO).

18. Overproduction without sufficient information related to un-centralized and unorganized inventory and inventory information.

19. Fire in finished goods warehouse because of raw materials for flammable toys; no established procedures for fire prevention.

20. Inaccurate inventory information because the finished goods inventory is not supported by adequate documentation and regularly updated existing information.

e) Risk in Finished Goods Delivery

21. Delays in delivery due to low oversight on shipments using company vehicles.

22. Goods broken in transit due to use of open-air vehicles and rainy weather.

23. Goods sent not in accordance with order because of manual product identification and limited access to the sales order in the warehouse.

24. Theft of goods during shipping because of low supervision of shipments in company vehicles; no employees specially assigned to deliver orders.

\section{Risk Mitigation by Company}

1. Purchase and pick up raw materials directly at supplier location.

2. Make purchases of raw materials according to quantity of customer orders.

3. Using the "made by order" production method.

4. Having several separate warehouses.

5. Educating employees not to smoke or discard cigarettes in the warehouse.

6. Rotation of work and restrictions on employees' working hours.

7. Asking to use a mask.

8. Designing semi-permanent set-up.

9. Simple inventory recording.

10. Improving marketing methods.

11. Use of logistic or courier service.

12. Plastic wrapping. 


\section{Risk Management Analysis}

a. Setting the context includes establishing the purpose of risk management, scope of work, company's objectives, internal and external factors, and assessing criteria of possibilities, impact, and levels of risk. Table I shows 5 risk impact level. Table II shows 5 risk possibility level. Figure 1 shows risk matrix based on risk impact and possibility. Table III shows risk level criteria.

TABLE I. RISK IMPACT CRITERIA

\begin{tabular}{|c|c|c|}
\hline Score & Level & Description \\
\hline 5 & Extreme & $\begin{array}{ll} & \text { Potential financial loss }>\text { Rp20.000.000 } \\
\text { - } & \text { Barriers to production }>8 \text { hours } \\
\text { - } & \text { Customer complaints }>13 \text { complaints }\end{array}$ \\
\hline 4 & Major & $\begin{array}{ll}- & \text { Potential financial loss Rp15.000.00 }<\mathrm{P}<\mathrm{Rp} 20.000 .000 \\
\text { - } & \text { Barriers to production 7-8 hours } \\
\text { - } & \text { Customer complaints 10-12 complaints }\end{array}$ \\
\hline 3 & Moderate & $\begin{array}{ll} & \text { Potential financial loss Rp10.000.000 }<\mathrm{P}<\mathrm{Rp} 15.000 .000 \\
\text { - } & \text { Barriers to production 5-6 hours } \\
\text { - } & \text { Customer complaints 7-9 complaints }\end{array}$ \\
\hline 2 & Minor & $\begin{array}{ll} & \text { Potential financial loss Rp5.000.000 }<\mathrm{P}<\mathrm{Rp} 10.000 .000 \\
\text { - } & \text { Barriers to production 3-4 hours } \\
\text { - } & \text { Customer complaints 4-6 complaints }\end{array}$ \\
\hline 1 & Incidental & $\begin{array}{ll}- & \text { Potential financial loss }<\text { Rp5.000.000 } \\
- & \text { Barriers to production } 1-2 \text { hours } \\
- & \text { Customer complaints }>3 \text { complaints }\end{array}$ \\
\hline
\end{tabular}

TABLE II.

RISK POSSIBILITY CRITERIA

\begin{tabular}{|l|l|l|}
\hline Score & Level & Description \\
\hline 1 & Very rare & It may happen once in 3 years. \\
\hline 2 & Less possible & It happened 1 time in 1 year. \\
\hline 3 & Maybe & It happened once in 4 months. \\
\hline 4 & Very likely & It happened 1 time in 1 month. \\
\hline 5 & Almost & It happened more than once in 1 month. \\
\hline
\end{tabular}

\begin{tabular}{|c|c|c|c|c|c|c|}
\hline & \multicolumn{5}{|c|}{ Possibility } \\
\hline & & $\begin{array}{c}\text { Very Rare } \\
\text { (1) }\end{array}$ & $\begin{array}{l}\text { Less Possible } \\
\text { (2) }\end{array}$ & $\begin{array}{l}\text { Maybe } \\
\text { (3) }\end{array}$ & $\begin{array}{c}\text { Very Likely } \\
\text { (4) }\end{array}$ & $\begin{array}{l}\text { Almost } \\
\text { (5) }\end{array}$ \\
\hline \multirow{5}{*}{ 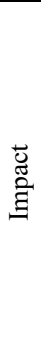 } & $\begin{array}{l}\text { Extreme } \\
\text { (5) }\end{array}$ & $\begin{array}{c}\text { Moderate } \\
(5 \times 1)\end{array}$ & $\begin{array}{l}\text { High } \\
(5 \times 2)\end{array}$ & $\begin{array}{c}\text { Extreme } \\
(5 \times 3)\end{array}$ & $\begin{array}{c}\text { Extreme } \\
(5 \times 4)\end{array}$ & $\begin{array}{l}\text { Extreme } \\
(5 \times 5)\end{array}$ \\
\hline & $\begin{array}{c}\text { Major } \\
\text { (4) }\end{array}$ & $\begin{array}{l}\text { Low } \\
(4 \times 1)\end{array}$ & $\begin{array}{l}\text { Moderate } \\
(4 \times 2)\end{array}$ & $\begin{array}{l}\text { High } \\
(4 \times 3)\end{array}$ & $\begin{array}{c}\text { Extreme } \\
(4 \times 4)\end{array}$ & $\begin{array}{c}\text { Extreme } \\
(4 \times 5)\end{array}$ \\
\hline & $\begin{array}{c}\text { Moderate } \\
\text { (3) }\end{array}$ & $\begin{array}{l}\text { Low } \\
(3 \times 1) \\
\end{array}$ & $\begin{array}{c}\text { Moderate } \\
(3 \times 2)\end{array}$ & $\begin{array}{c}\text { Moderate } \\
(3 \times 3)\end{array}$ & $\begin{array}{l}\text { High } \\
(3 \times 4)\end{array}$ & $\begin{array}{l}\text { Extreme } \\
(3 \times 5)\end{array}$ \\
\hline & $\begin{array}{l}\text { Minor } \\
(2)\end{array}$ & $\begin{array}{l}\text { Low } \\
(2 \times 1)\end{array}$ & $\begin{array}{l}\text { Low } \\
(2 \times 2)\end{array}$ & $\begin{array}{l}\text { Moderate } \\
(2 \times 3)\end{array}$ & $\begin{array}{l}\text { Moderate } \\
(2 \times 4)\end{array}$ & $\begin{array}{l}\text { High } \\
(2 \times 5)\end{array}$ \\
\hline & $\begin{array}{l}\text { Incidental } \\
\text { (1) }\end{array}$ & $\begin{array}{l}\text { Low } \\
(1 \times 1)\end{array}$ & $\begin{array}{l}\text { Low } \\
(1 \times 2)\end{array}$ & $\begin{array}{l}\text { Low } \\
(1 \times 3)\end{array}$ & $\begin{array}{l}\text { Low } \\
(1 \times 4)\end{array}$ & $\begin{array}{l}\text { Moderate } \\
(1 \times 5)\end{array}$ \\
\hline
\end{tabular}

Fig. 1. Risk Matrix

TABLE III. RISK LEVEL CRITERIA

\begin{tabular}{|l|l|l|}
\hline \multicolumn{1}{|c|}{ Risk Level } & \multicolumn{1}{c|}{ Score } & \multicolumn{1}{c|}{ Action } \\
\hline Low & $\mathrm{X}<4$ & $\begin{array}{l}\text { Does not require any special mitigation. Risk is acceptable } \\
\text { (acceptable). }\end{array}$ \\
\hline Moderate & $5<\mathrm{X}<9$ & Recommend mitigation where possible \\
\hline High & $10<\mathrm{X}<12$ & Mitigation is needed to manage risk. Risk is a problem. \\
\hline Extreme & $\mathrm{X}>13$ & $\begin{array}{l}\text { Immediate risk mitigation is needed. Risk is unacceptable } \\
\text { (unacceptable). }\end{array}$ \\
\hline
\end{tabular}

b. Risk Identification. Based on interviews and observations, the following is a list of risks (risk registers), circumstances that triggered a risk (risk events), and risk categories that can be identified in the inventory cycle of PT HS. Risk identification includes all risks explained in Risk Identification. c. Risk Analysis. Table IV shows list of observed risks (risk register) and levels of risk determined based on levels of possibility and impact according to predetermined criteria. Risks are identified risk without considering the company's existing control efforts. 
TABLE IV. RISK REGISTER ANALYSIS

\begin{tabular}{|c|c|c|c|c|c|c|c|c|c|c|}
\hline \multirow[t]{2}{*}{ No } & \multirow[t]{2}{*}{ Risk } & \multicolumn{3}{|c|}{$\begin{array}{l}\text { Inherent } \\
\text { Risk }\end{array}$} & \multirow[t]{2}{*}{ Mitigation by Company } & \multicolumn{3}{|c|}{$\begin{array}{c}\text { Residual } \\
\text { Risk }\end{array}$} & \multirow[t]{2}{*}{$\begin{array}{l}\text { Risk } \\
\text { Level }\end{array}$} & \multirow{2}{*}{$\begin{array}{l}\text { Risk } \\
\text { Priority } \\
\text { Rank }\end{array}$} \\
\hline & & I & $\mathrm{P}$ & $\mathrm{S}$ & & I & $\mathrm{P}$ & $\mathrm{S}$ & & \\
\hline 1 & $\begin{array}{l}\begin{array}{l}\text { Buying } \\
\text { quality }\end{array} \\
\end{array}$ & 2 & 4 & 8 & $\begin{array}{l}\text { Purchase and pick up raw materials directly } \\
\text { at the supplier's location }\end{array}$ & 1 & 3 & 3 & $\mathrm{~L}$ & 23 \\
\hline 2 & Purchasing unnecessary raw materials & 3 & 3 & 9 & $\begin{array}{l}\text { Make purchases of raw materials in accord } \\
\text { with the quantity of customer orders }\end{array}$ & 1 & 2 & 2 & $\mathrm{~L}$ & 24 \\
\hline 3 & Inaccurate raw materials recording & 4 & 4 & 16 & Not available & 4 & 4 & 16 & E & 1 \\
\hline 4 & Unreliable supplier & 2 & 4 & 8 & $\begin{array}{l}\text { Purchase and pick up raw materials directly } \\
\text { at supplier location }\end{array}$ & 2 & 3 & 6 & $\mathrm{M}$ & 12 \\
\hline 5 & $\begin{array}{l}\text { Receiving raw materials that do not } \\
\text { fit the order }\end{array}$ & 2 & 3 & 6 & $\begin{array}{l}\text { Purchase and pick up raw materials directly } \\
\text { at supplier location }\end{array}$ & 2 & 2 & 4 & $\mathrm{~L}$ & 18 \\
\hline 6 & Decreasing quality of raw materials & 3 & 4 & 12 & Using "made by order" production method & 2 & 4 & 8 & $\mathrm{M}$ & 9 \\
\hline 7 & Loss of raw materials & 4 & 4 & 16 & Not available & 4 & 4 & 16 & E & 2 \\
\hline 8 & Loss of raw materials due to fire & 5 & 1 & 5 & $\begin{array}{l}\text { Having several separate warehouses } \\
\text { Educating employees not to smoke or to } \\
\text { discard cigarette butts in the warehouse } \\
\text { area }\end{array}$ & 5 & 1 & 5 & $\mathrm{M}$ & 15 \\
\hline 9 & Late purchases of raw materials & 2 & 3 & 6 & Not available & 2 & 3 & 6 & $\mathrm{M}$ & 13 \\
\hline 10 & $\begin{array}{l}\text { Working accidents of production } \\
\text { operators }\end{array}$ & 3 & 4 & 12 & $\begin{array}{l}\text { Rotation of work and restrictions on } \\
\text { working hours of employees }\end{array}$ & 3 & 3 & 9 & $\mathrm{M}$ & 6 \\
\hline 11 & $\begin{array}{l}\text { Health problems of production } \\
\text { operators }\end{array}$ & 3 & 3 & 9 & Ask to use a mask & 3 & 3 & 9 & $\mathrm{M}$ & 7 \\
\hline 12 & The wood is moldy & 2 & 5 & 10 & Not available & 2 & 5 & 10 & $\mathrm{H}$ & 5 \\
\hline 13 & $\begin{array}{l}\text { Cutting of timber does not meet } \\
\text { specifications }\end{array}$ & 1 & 5 & 5 & $\begin{array}{l}\text { Rotation of work and restrictions on } \\
\text { working hours of employees } \\
\text { Designing semi-permanent set-up }\end{array}$ & 1 & 5 & 5 & $\mathrm{M}$ & 16 \\
\hline 14 & Power outage & 3 & 5 & 15 & $\begin{array}{l}\text { Rotation of work and restrictions on } \\
\text { working hours of employees }\end{array}$ & 3 & 4 & 12 & $\mathrm{H}$ & 3 \\
\hline 15 & $\begin{array}{l}\text { Decreased performance of production } \\
\text { machinery }\end{array}$ & 2 & 4 & 8 & Not available & 2 & 4 & 8 & $\mathrm{M}$ & 10 \\
\hline 16 & Loss of finished goods inventory & 4 & 3 & 12 & $\begin{array}{l}\begin{array}{l}\text { Record preparation of finished goods } \\
\text { simply }\end{array} \\
\end{array}$ & 3 & 3 & 9 & $\mathrm{M}$ & 8 \\
\hline 17 & $\begin{array}{l}\begin{array}{l}\text { Obsolescence } \\
\text { inventory }\end{array} \\
\text { of finished goods } \\
\end{array}$ & 4 & 4 & 16 & $\begin{array}{l}\text { Using "made by order" production method } \\
\text { Improve marketing methods }\end{array}$ & 2 & 3 & 6 & $\mathrm{M}$ & 14 \\
\hline 18 & Overproduction & 2 & 4 & 8 & Using "made by order" production method & 2 & 2 & 4 & $\mathrm{~L}$ & 19 \\
\hline 19 & Fire warehouse of finished goods & 5 & 1 & 5 & $\begin{array}{l}\text { Having several separate warehouses } \\
\text { Educating employees not to smoke or to } \\
\text { discard cigarette butts in the warehouse } \\
\text { area }\end{array}$ & 5 & 1 & 5 & $\mathrm{M}$ & 17 \\
\hline 20 & Inaccurate inventory information & 2 & 5 & 10 & $\begin{array}{lllll}\begin{array}{l}\text { Record preparation of finished goods } \\
\text { simply }\end{array} & & & \\
\end{array}$ & 2 & 4 & 8 & $\mathrm{M}$ & 11 \\
\hline 21 & Delays in delivery & 1 & 4 & 4 & Use of courier services & 1 & 4 & 4 & $\mathrm{~L}$ & 20 \\
\hline 22 & Goods broken in transit & 3 & 4 & 12 & Use of courier services & 2 & 2 & 4 & $\mathrm{~L}$ & 21 \\
\hline 23 & $\begin{array}{l}\text { Goods sent not in accordance with } \\
\text { the order }\end{array}$ & 2 & 2 & 4 & Not available & 2 & 2 & 4 & $\mathrm{~L}$ & 22 \\
\hline 24 & $\begin{array}{l}\text { Theft of the goods while being } \\
\text { shipped }\end{array}$ & 4 & 3 & 12 & Use of courier services & 4 & 3 & 12 & $\mathrm{H}$ & 4 \\
\hline
\end{tabular}

\section{Remarks :}

$\begin{array}{llll}\mathrm{I} & : \text { Impact } & \mathrm{L} & : \text { Low } \\ \mathrm{P} & : \text { Possibility } & \mathrm{M} & : \text { Moderate } \\ \mathrm{S} & : \text { Score } & \mathrm{H} & : \text { High } \\ & & \mathrm{E} & : \text { Extreme }\end{array}$

d. Risk Evaluation. The risk analysis conducted is the basis of risk evaluation, at which stage the researcher makes decisions based on the residual value of risk from the previous stage. Figure 2 shows a risk matrix maps risks within extreme, high, moderate, and low categories

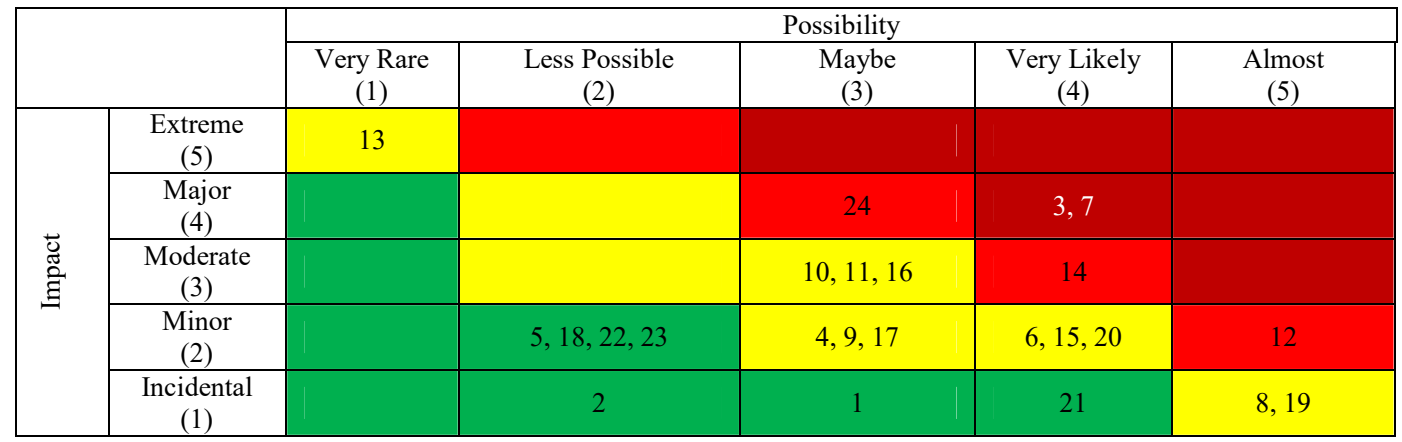

Fig. 2. Risk Matrix 
Mapped risks are determined according to the scale of their priorities. Based on mapping, some risks do not require special mitigation and are acceptable to the company; this is further categorized as risk appetite, for instance:

- Risk 1: Buying raw materials with low quality

- Risk 2: Purchasing unnecessary raw materials

- Risk 5: Receiving raw materials which not fit the order

- Risk 18: Overproduction

- Risk 21: Delays in delivery

- Risk 22: Goods broken in transit

- Risk 23: Goods sent not in accordance with orders

Company Activities to Optimize Risk Management Design

Risk Treatment

Extreme, high, and moderate risks are classified, and mitigation actions are proposed to reduce the possibility of risk occurrence and its impact, as follows:

a. Extreme Risk

- Organizing and grouping goods according to type

- Recording computerized inventory for raw materials and finished goods inventory

- Periodical stock counting procedure b. High Risk

- Use of online logistics services

- Procurement of backup power tools

- Supplying a wood drying machine

b. Moderate Risk

- Designing safety standards

- Personal and cultural approaches to health and safety

- Person in charge of warehouse

- Internet access to enable centralized system of inventory data

- Inventory management uses the FIFO method

- Regular maintenance procedures

- Evaluate suppliers regularly

\section{Monitoring and Review}

Table V shows risk maturity assessment shows that the company could improve its risk maturity from naïve to the higher, defined level.

TABLE V. RISK MATURITY ASSESSMENT COMPARISON AFTER RISK MANAGEMENT APPLICATION

\begin{tabular}{|c|c|c|c|}
\hline No. & Characteristics & $\begin{array}{c}\text { Before Risk } \\
\text { Management }\end{array}$ & After Risk Management \\
\hline 1 & Organization's objectives are defined. & Possibly & Yes \\
\hline 2 & $\begin{array}{l}\text { Management have been trained to understand what the risks } \\
\text { are and their responsibility for them. }\end{array}$ & No & Yes \\
\hline 3 & A scoring system for assessing risk has been defined. & No & Yes \\
\hline 4 & $\begin{array}{l}\text { The risk appetite of the organization has been defined in } \\
\text { terms of the scoring system. }\end{array}$ & No & Yes \\
\hline 5 & $\begin{array}{l}\text { Processes have been defined to determine risks, and these } \\
\text { have been followed. }\end{array}$ & No & Yes \\
\hline 6 & $\begin{array}{l}\text { All risks have been collected into one list; risks have been } \\
\text { allocated to specific job titles. }\end{array}$ & No & Yes \\
\hline 7 & $\begin{array}{l}\text { All risks have been assessed in accordance with the defined } \\
\text { scoring system. }\end{array}$ & No & Yes \\
\hline 8 & $\begin{array}{l}\begin{array}{l}\text { Responses to each risk have been selected and } \\
\text { implemented. }\end{array} \\
\end{array}$ & No & Yes \\
\hline 9 & $\begin{array}{l}\text { Management has established methods to monitor proper } \\
\text { operation of key processes, responses, and action plans } \\
\text { ("monitoring controls"). }\end{array}$ & No & Yes \\
\hline 10 & The organization regularly reviews risks. & No & Yes \\
\hline 11 & $\begin{array}{l}\text { Management reports risks to departments where responses } \\
\text { have not managed risks at a level acceptable to the board }\end{array}$ & No & Yes \\
\hline 12 & All significant new projects are routinely assessed for risk. & No & No \\
\hline 13 & $\begin{array}{l}\text { Responsibility for determination, assessment, and } \\
\text { management of risks is included in job descriptions. }\end{array}$ & No & $\begin{array}{l}\text { Identification, assessment and risk management may be } \\
\text { covered in job description limited to managerial level }\end{array}$ \\
\hline 14 & $\begin{array}{l}\text { Managers provide assurance on their risk management's } \\
\text { effectiveness. }\end{array}$ & No & No \\
\hline 15 & $\begin{array}{l}\begin{array}{l}\text { Managers are assessed on their risk management } \\
\text { performance. }\end{array} \\
\end{array}$ & No & No \\
\hline 16 & Internal audit approach & No & $\begin{array}{l}\text { Management already cooperates with risk management } \\
\text { and started using assessment of identified risks }\end{array}$ \\
\hline
\end{tabular}




\section{CONCLUSION AND SUgGESTIONS}

\section{A. Conclusion}

This research has identified the risks contained in the inventory cycle in the company. These risks are identified from observations and interviews with those who have a direct involvement in the inventory cycle. Risks that have been identified are then evaluated by evaluating the risks that have been identified without considering the controls carried out by the company. Further risk evaluation is carried out by considering operational activities that can mitigate risk, both reducing the impact and the possibility of the occurrence of risks. Furthermore, this study proposes mitigation efforts that can be considered by companies in an effort to reduce the negative impact of risk. This research also increases the level of risk maturity of the company. The risk maturity assessment conducted at the beginning and end of the study shows that the level of the company's risk maturity has increased from the naïve risk level to the risk defined.

\section{B. Research Implications}

1. Results of analysis at the risk identification and risk impact stages are a set of operational risks in the inventory cycle that has the potential to affect the manufacturing company's financial condition, profitability, and performance.

2. Analysis results in the corporate risk mitigation stage are a collection of risk mitigations by the company that potentially reduce the possibility and impact of risk. The company can maintain and improve these operations because it can mitigate several existing risks.

3. Analysis results in the risk analysis phase are risk register and risk level classification that can help the company determine the priority scale in handling risk. The company has also determined which risk is acceptable and thus determined the risk appetite.

4. Analysis results in the risk treatment stage are proposals to mitigate the company's residual risk. Proposed mitigation was designed by adjusting the company's conditions and capabilities as a medium-sized business that certainly has different capabilities than large businesses. The mitigation proposal also included allocation of the designated party to handle the risk since the company has not yet formed a special department to deal with risks collectively.

5. As a result of risk maturity assessment conducted after the research, the researcher concludes that the company has been able to communicate strategy. Identified risks can be communicated between departments at the management level, so that appropriate employees are aware of risks' aspects and their responsibilities. The company has also defined its risk appetite. At this stage, the company has increased its level of risk maturity.

\section{Research Limitations}

This study has several limitations that can be used as the foundation of future research, including the following.

1. This research is limited to a wood processing industry with a small to medium business scale, so the chances of risks identified here might not be applicable to larger industries.

2. The research object does not have an adequate documentation system, so this research is not supported by physical documentation.

3. The researcher's limited access to the company's accounting and finance areas serves as this study's limitation in deepening understanding of risk findings through their impact on financial reports, which might potentially be affected by risk.

4. This research focuses on identifying operational risks in inventory cycles.

5. This study is limited to physical flow in the inventory cycle, but does not include inventory valuation calculations because of researchers' limited access to the firm's financial area. Financial criteria in this study were determined based on management interviews and assumptions.

\section{Suggestions for further research}

Further research might do any or all of the following:

1. May expand risk analysis to other types of industries and business scales.

2. Be supported by physical documentation to improve research reliability.

3. Deepen analysis by linking risk impact with impact on financial statements, so that an applied analysis can be more feasible as the basis of strategic financial decision making.

4. May expand identification of other risk types to broaden the company's view of risk in the inventory cycle.

5. Deepen analysis related to inventory cycle by including inventory valuation calculation, so that the research object can have more mature consideration in decision making.

\section{ACKNOWLEDGEMENT}

We thank our colleagues from Universitas Indonesia who provided insight and expertise that greatly assisted the research, although they may not agree with all of the interpretations/conclusions of this paper.

We thank Dr. Gede Harja Wasista, CMA, as as Chair of the Accounting Master Study Program, and Dr. Lianny Leo, S.E., M.Si., BAP., for assistance with particular technique and methodology, and also for comments that greatly improved the manuscript.

We would also like to show our gratitude to the Dr. Bernard E. Tidajoh, S.E., M.S.Ak. and Mrs. Rafika Yuniasih S.E., AK., for their comments on an earlier version of the manuscript, although any errors are our own 
and should not tarnish the reputations of these esteemed persons. We also immersely grateful to PT HS management for every chance given for this research.

\section{REFERENCES}

[1] Industry News: Indonesia is in the Top 10 in Manufacturing. (2017, October 3). Retrieved from Ministry of Industry: http://www.kemenperin.go.id/artikel/15069/Indonesia-Masuk-10Besar-Manufaktur

[2] Arens, A. A., Elder, R. J., \& Beasley, M. S. (2013). Auditing and assurance services: An integrated approach, 15th Edition. Harlow: Pearson Education Limited.

[3] Rapina, \& Christyanto, L. (2011). The Role of Internal Control Systems in Improving the Effectiveness and Efficiency of Operational Activities in Inventory and Warehousing Cycle (Case Study at PT. Ullajaya Milk Industry \& Trading Company Tbk Bandung). Akurat Accounting Scientific Journal, 06 Year 2.

[4] COSO. (2004). Enterprise Risk Management - Integrated Framework: Executive Summary.

[5] Moeller, R. R. (2009). Brink's modern internal auditing: a common body of knowledge, 7th ed. Canada: John Wiley \& Sons.

[6] Ekwere, N. (2016). Framework of Effective Risk Management in Small and Medium Enterprise (SMEs): A Litterature Review. Bina Ekonomi Volume 20 Nomor 1, 23-44.

[7] Watt, J. (2007). Strategic Risk Management for Small Business. Managing Business Risk: a Practical Guide to Protecting Your Business, 31-40.

[8] Brustbauer, J. (2016). Enterprise Risk Management in SMEs: Towards a Structural Model. International Small Business Journal, 34(1), 70-85

[9] Gjerdrum, D., \& Peter, M. (2012, April 5). The New International Standard on the Practice of Risk Management - A Comparison of ISO 31000:2009 and the COSO ERM Framework. Retrieved from The Institute of Internal Auditors North America: https://na.theiia.org/standards-guidance/Public\%20Documents/7-2$\% 20$ Article_on_ISO_for_Auditors_rev7-20.pdf

[10] Halonen, P. (2014). Risk-Based Evaluation of Internal Controls in Case Company's Sales Process. Retrieved from Aalto University Institutional Repository: https://aaltodoc.aalto.fi
[11] Jensen, M., \& Meckling, W. (1976). Theory of the Firm: Managerial Behaviour, Agency Cost, and Ownership Stucture. Journal of Finance Economic, 3, 305-360.

[12] Villalonga, B., \& Amit, R. (2006). How do family ownership, control and management affect firm value? Journal of Financial Economics, 80(2), 385-417.

[13] Scott, W. R. (2011). Financial Accounting Theory Sixth Edition. Canada: Prentice Hall.

[14] Ang, J. S. (1991). Small business uniqueness and the theory of financial management. The Journal of Small Business Finance, $1(1), 1-13$.

[15] ISO. (2009, 11). ISO 31000:2009 Risk management -- Principles and guidelines. Retrieved from International Organization for Standardization: https://www.iso.org

[16] Kasidi. (2010). Risk Management, Ed. 1. Bogor: Ghalia Indonesia Publisher.

[17] Hanafi, M. M. (2012). Risk Management, Ed. 2. Yogyakarta: UPP STIM YKPN.

[18] Darmawi, H. (2005). Risk Management. Jakarta: Bumi Aksara Publisher.

[19] Pickett, K. H. (2005). The Essential Handbook of Internal Auditing. Chichester: John Wiley \& Sons Ltd.

[20] Drennan, L. T. (2007). Risk and Crisis Management in The Public Sector. New York: Routledge Taylor \& Francis Group.

[21] Benli, V. F., \& Celayir, D. (2014). Risk Based Internal Auditing and Risk Assessment Process. European Journal of Accounting Auditing and Finance Research, 1-16.

[22] The Institute of Chartered Accountants of India. (2007). Guide on Risk-based Internal Audit. New Delhi: The Institute of Chartered Accountants of India.

[23] Rangkuti, F. (1996). Inventory Management: Application in the Business Field, Ed. 2. Jakarta: PT RajaGrafindo Persada.

[24] Yin, R. K. (2003). Case Study Research : Design and Methods 3rd edition. California: Sage Publications, Inc.

[25] Wahyuni, S. (2015). Qualitative Research Method: Theory and Practice. Jakarta: Salemba Empat.

[26] Yin, R. K. (2003). Case Study Research : Design and Methods 3rd edition. California: Sage Publications, Inc. 